small star from Venus, Io minutes 20 seconds. Venus then appeared very distinctly, and the sky being very clear, he took eyepieces three or four times more powerful, and saw, with an agreeable surprise, that the small star showed a phase, and the same phase as Venus; its diameter was rather less than a third of that of Venus, its light not so vivid but well defined; the great circle which passed through the centres of Venus and of the satellite, which it would be difficult to designate otherwise, made an angle of about 18 to 20 degrees with the equator, the satellite being a little towards the north, and preceding Venus in right ascension. Mr. Short examined it at different times and with different telescopes during the space of an hour, until the light of day or of the twilight obliterated it entirely."

It will be seen that Short's observation, divested of the typographical error in the Phil. Trans., by which it was confused, is intelligible enough, and it may not be without interest if we examine the circumstances under which it must have been made.

Taking the place of Venus with sufficient precision for the purpose in view from the tables of Le Verrier, we have the following figures:-It may be premised that the date given in NATURE last week from the Phil. Trans, is the morning of October 23 , but it is to be remembered that the Gregorian style had not then been introduced in this country; in the present mode of reckoning, it becomes the morning of November 3, as stated in the "Histoire de l'Acarlemie."

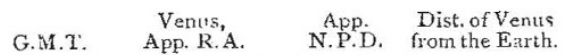
I740, Nov. 2 , at $18^{\mathrm{h}} 30^{\mathrm{m}} \mathrm{I}^{\prime} 75^{\circ} 2 \mathrm{I}^{\prime} \mathrm{II}^{\prime \prime} 87^{\circ} \mathrm{I}^{\prime} 2 \mathrm{I}^{\prime \prime} \quad 0^{\prime \prime} 7007$.

Hourly motion in R.A. $+2^{\prime} 28^{\prime \prime}$; in N.P. D + $0^{\prime} 49^{\prime \prime}$.

The apparent diameter of Venus (Le Verrier) was $23^{\prime \prime} \cdot 7$, and her heliocentric longitude being $86^{\circ} \mathrm{r} \mathrm{I}^{\prime}$, and her geocentric longitude $174^{\circ} 38^{\prime}$; the breadth of the illuminated portion of her disc was 0.514 ; elongation, W. $462^{\circ}$.

Short says the daylight put a stop to his observations "about a quarter of an hour after eight," which we may assume to imply apparent time, and as the correction from apparent to mean time was then $I 6^{\mathrm{m}} \cdot \mathrm{I}$ subtractive, his observation may be supposed to have terminated at 8 A.M., and as he had viewed the object during the space of an hour, we find Venus must have been at an altiturle of $36^{\circ}$ when he first perceived it, and further, it should be noted, the sun rose at $7^{\mathrm{h}} \mathrm{o}^{\mathrm{m}}$, so that Short's observations must have been made entirely in daylight, with the planet particularly well situated.

The suspected satellite was $18^{\circ}-20^{\circ}$ north-preceding Venus, which implies a mean angle of position of $289^{\circ}$, and as the distance was $10^{\prime} 20^{\prime \prime}$, we have for the difference of right ascension, $39^{\circ} \mathrm{k}$, and for the difference of N.P.D., $3^{\prime} 22^{\prime \prime}$. Supposing these differences to apply to $7^{\mathrm{h}} 30^{\mathrm{m}}$ A.M., the position of the object would be R.A. I I $I^{\text {h }} 40^{\mathrm{m}} 50^{\mathrm{s} \cdot 6}$, N.P.D. $87^{\circ} 9^{\prime} 23^{\prime \prime}$; whence, bringing forward to the epoch of the Durchmusterung, its R.A. is $\mathrm{II}^{\mathrm{h}} 46^{\mathrm{m}} 46^{\mathrm{s}}$, N.P.D. $87^{\circ} 47^{\prime} 5$ for $1855^{\circ}$.

Unless we had been able to correct the misprint in the Phil. Irans. by the French account of the observation, it might, perhaps, have been inferred that the distance was intended to be $I^{\circ} 2^{\prime}$ or $I^{\circ} 12^{\prime}$, and in this case the 3.4 magnitude star $\beta$ Virginis would have fallen very nearly upon Short's position; at 7 A.M. this star preceded Venus $1^{\circ} 5^{\prime}$, and was N. $26^{\prime}$.

It will be found that our examination of Short's observation does not tend to explain it. Though Lalande thought when conversing with him on the subject in 1763 , that he doubted his having observed a satellite of Venus, he appears to have been sufficiently impressed with his observation to have had the appearance engraved, and to have "carried it with him as a seal."

The observation of Andreas Mayer at Greifswald, mentioned in NATURE last week in the notice of Schorr's "Der Venusmond," was communicated to Lambert after the appearance of his memoir "Essai d'une théorie du satellite de Vénus," in the Berlin Memoirs, 1773, of which an abstract is found in the Astronomisches $\widetilde{f}$ ahrbuch, I777. It is printed at p. I86 of the $7 a h r b u c h$ for $I 778$, where also appear the two letters from Abraham Scheuten to Lambert, referring to his observations of what he believed to be a satellite of Venus, after the planet had left the sun's disc in the transit of $176 \mathrm{r}$, June 6 , which at noon at Crefeld was near the centre of the disc and at 3 P.M., near the limb. Lambert follows with a particular examination of Scheuten's observation in connection with the observations of Montaigne at $\mathrm{Li}$ moges in May preceding.

$\gamma$ ARGUS.--Gilliss, in the notes to the 1850 " Catalogue of Double Stars observed at Santiago," remarks of this object: "The cluster deserves special attention for its evident changes since Herschel's observations." From a comparison of the observations it is not obvious to what changes reference is here made. Perhaps some reader of NATURE who can favourably command this star's position will describe the actual configuration, \&c. of the principal star and vicince.

Mr. S. M. Drach writes with reference to views of binary stars from Venus and Mars: "Has it ever been noticed by cosmographists that an observer at these planets must see our moon at a maximum elongationangle from our earth, ranging from Venus from $5 \frac{1}{1} 1$ to $3 I_{4}^{\frac{1}{4}}$ minutes of degree, and from Mars from $3 \frac{1}{2}$ to $166_{6}^{5}$ minutes of degree, whence follows that our present century's certitude of Binary Stellar Systems is a PRIMITIVE feature of naked-eye astronomy to the Venus or IVars observers. This elongation diminishes to zero in about seven days of either planet, since their rotation periods nearly equal the earth's."

\section{THE NORWEGIAN-ATLANTYC EXPEDITION}

THIS Expedition left Bergen Jure I for the Sognefiord, where the first week was spent in preparatory worksounding, dredging, and trawling in 600 fathoms. The temperature at the bottom was found exactly the same as in former years, $43^{\circ} .7 \mathrm{~F}$. The fauna was a mixture of Atlantic and Arctic. There were found several specimens of Brisinga coronata (Sars), Munida tenuimana, one large Activiz and a sponge, Tisiphonia agariciformis, and, among other mollusca, Aximus eumyarius (Sars), Kelliella abyssicola (Sars), Malletia obtusa, and Taranis $n_{1}$ örchi. The second week was spent at Hüso, a small island at the mouth of the Sognefiord, where magnetical base-observations were made on shore and on board, ship swung for deviation, \&c.

June 20 the Expedition left this place, and steered along the deep channel surrounding Southern Norway from the Skagerrack up to Cape Stadt. The first soundings and dredgings showed a very flat bottom at a depth of about 200 fathoms, and with a fauna mainly Atlantic. About 150 miles N.W. of Cape Stadt the temperature began to fall, the depth remaining unchanged. At the next sounding the depth increased and the bottom temperature was still falling, until at last the Miller-Casella thermometer showed $32^{\circ}$ at 300 fathoms, and $30^{\circ}$ at the bottom in 400 fathoms. This is exactly like what the Porcupine found in the Lightning Channel. Off Stadt the fauna was Arctic and Glacial. Among the specimens brought up was a gigantic Umbellularia, 5 feet high, a Nymphon, Io inches between the ends of the feet, a new large Archaster, and many other characteristic forms. No less than eight forms of Hydroids were also found at this depth, three different species of Arctic Fusus, and several specimens of Yoldia intermedia, \&c.

The Expedition ran into Christiansund June 23, and was to leave that port in a few days for the Faraes and Iceland. 